\title{
Correction to: Characterization of Liquids Using Electrical Properties in Microwave and Millimeter Wave Frequency Bands
}

\section{Turgut Ozturk ${ }^{1}$ D}

Published online: 19 March 2020

c) Springer Science+Business Media, LLC, part of Springer Nature 2020

\section{Correction to:}

Journal of Nondestructive Evaluation (2019) 38:11 https://doi.org/10.1007/s10921-018-0553-6

Unfortunately, the author had missed to include the below acknowledgement text in the original publication of the article. This has been corrected with this erratum.
Acknowledgements The author thanks Ilhami Ünal and Aysun Sayinti for providing the measurement data made at Marmara Research Center of TUBITAK.

Publisher's Note Springer Nature remains neutral with regard to jurisdictional claims in published maps and institutional affiliations.

The original article can be found online at https://doi.org/10.1007/ s10921-018-0553-6.

Turgut Ozturk turgutozturk@live.com

1 Department of Electrical-Electronics Engineering, Bursa Technical University, Bursa, Turkey 